\title{
Correlation between Beck Depression Inventory and World Health Organization Quality of Life-BREF Scores in Stage III of Human Immunodeficiency Virus/Acquired Immune Deficiency Syndrome Patients at Central Public Hospital of Pusyansus RSUP Haji Adam Malik Medan
}

\author{
Erlina Yulia, Mustafa M. Amin*(i), Bahagia Loebis, Nazli M. Nasution \\ Department of Psychiatry, Faculty of Medicine, Universitas Sumatera Utara, Medan, Indonesia
}

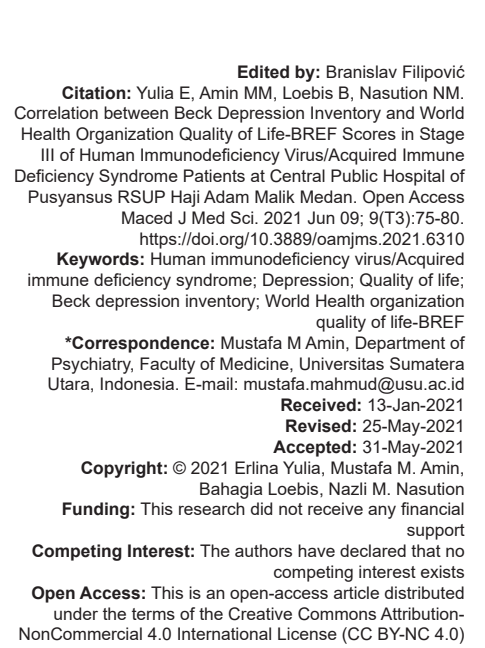

Abstract

BACKGROUND: Depression is a psychiatric complication that mostly associated with Human Immunodeficiency Virus (HIV) disease. For people in HIV positive infection stage, unstable and declining physical conditions followed by the appearance of physical symptoms and intense social pressure from the environment can be a source of stress that results in depression. After entering the stage of Acquired Immune Deficiency Syndrome (AIDS), depression is more susceptible to experience because of worsening health conditions. Furthermore, patients also often feel that their life will be not long so that everything that happens in his or her life will be in vain which will have an impact on their quality of life.

AIM: The objective of the study was to determine the correlation between Beck Depression Inventory (BDI) II and World Health Organization Quality of Life (WHOQOL-BREF) scores in stage III of HIVIAIDS patients at Pusyansus RSUP Haji Adam Malik Medan.

METHODS: This study is a cross-sectional study using a correlative analytic design, which was conducted at the Pusyansus Haji Adam Malik Hospital Medan, North Sumatra, from May 2019 to November 2019. The research subjects were 65 people diagnosed with HIVIAIDS stage III. The degree of depression was measured based on the BDI II and the quality of life was measured based on the WHOQOL-BREF.

CONCLUSION: There is a significant correlation between BDI II score and WHOQOL-BREF score in HIVIAIDS patients stage III at the RSUP Haji Adam Malik Medan Hospital.

\section{Introduction}

Acquired Immune Deficiency Syndrome (AIDS) is a group of symptoms or infections that arise due to damage to the human immune system because of the Human Immunodeficiency Virus (HIV) infection. HIV can weaken human immunity. It means that people who are exposed to this virus will become susceptible to opportunistic infections, that is, tuberculosis or prone to tumors [1]. HIV is an epidemic that has been developed into a global crisis. This disease also has a "window period" and a relatively long asymptomatic phase (without symptoms) in the course of the disease, this causes a pattern of its development similar to iceberg phenomena [2].

In 2013, there were 35 million people around the world had been diagnosed with HIV, including 16 million women and 3.2 million children aged $<15$ years old. The number of new HIV infections in 2013 was
2.1 million cases, consisting of 1.9 million adults and 240,000 children aged $<15$ years old. The number of deaths due to AIDS recorded was 1.5 million, consisting of 1.3 million adults and 190,000 children aged $<15$ years old [3].

In 2012, HIV and AIDS cases in North Sumatra, Indonesia that has been recorded were 2189 cases of $\mathrm{HIV}=$ and 4241 cases of AIDS. Further, in 2013, HIV and AIDS cases have been increased to 2916 cases of HIV and 4628 cases of AIDS. Not only that, but these cases also continued to increase, in which the number of HIV cases increased sharply from 3594 cases in 2014 to 5184 cases in 2015 and AIDS cases from 5625 cases in 2014 to 5660 cases in 2015 [4].

Medan is a city with the highest number of HIVIAIDS cases in North Sumatra, Indonesia. There was an increase in new cases of 506 cases (34.5\%) in 2012 and 421 cases (37.7\%) in 2013 of the total new cases. Based on the initial survey conducted at RSUD 
Dr. Pirngadi Medan, the number of HIVIAIDS cases that went for outpatient treatment was 109 cases in 2015 [4].

HIVIAIDS has become a health problem in the world since 1981, this disease has also become a pandemic. Drugs and vaccines to overcome this problem have not been found, which can cause but harm not only in the health sector also in the social, economic, political, cultural, and demographic fields [2].

Mood disorders, particularly depression, are the psychiatric complications commonly associated with HIV disease. According to Freud in his psychodynamic theory, psychosocial factors that influence depression including life events and environmental stressors, personality, psychodynamics, repeated failures, cognitive theory, and social support. Life events that cause stress more often precede the first episode of a mood disorder than upcoming episodes [5].

The lifetime prevalence of depressive disorders ranges from 22 to $61 \%$ in the HIV-positive population. These numbers were significantly higher than lifetime estimates and current diagnoses of major depression in the community sample. The prevalence of depression according to gender was not significantly different. But Nogueira et al. have reported an increased prevalence of depression in women higher than men [6].

Depression is not easily detected, as a consequence, patients with depression were not be treated in the general medical population. In primary care, doctors lose between half and two-thirds of patients experiencing depression. Depression is often seen as an expected reaction to medical illness. Bing et al. reported that as many as one in three people with HIV can suffer from depression. Depression in people living with HIVIAIDS (PLWHA) can be triggered by stress, difficult life events, drug side effects, or the effects of HIV on the brain and may even accelerate the progression of HIV to AIDS [6].

The economic costs of HIVIAIDS care for some people are considered enormous and often lead to patients and their families into poverty. At times, this leads to family ostracism, destroyed households, loss of jobs, and sale of assets to pay for hospitalization. Negative social consequences such as stigma have become the most problems faced by PLWHA. This often leads to problems of marriage, work, and can even lead to divorce decision. The stigma attached to this disease is often the main cause of patients with major depression [6].

From the research conducted by Bhatia, it was reported that depression level was increasing regarding the severity of HIVIAIDS. It was also reported that the prevalence of depression increased with the severity of symptoms. Thus, the more severe the disease, the greater the impact on the mental health of the patient. The prevalence of depression decreased with the duration of therapy. This can be attributed to the fact that the treatment process to reduce the symptoms of the disease will help the patient to achieve a better life [6].

The quality of life of PLWHA is also influenced by psychosocial problems. In particular, depression, which is the biggest psychosocial problem experienced by PLWHA is requiring serious handling because it can have an impact on the quality of life. According to David et al., the higher the level of depression in HIVIAIDS patients, the more it can reduce the quality of life [7].

In people with a positive HIV infection stage, unstable and declining physical conditions followed by the appearance of physical symptoms and the enormous social pressure obtained from the environment can be a source of stress that can cause PLWHA to experience depression. Furthermore, PLWHA who have entered the AIDS stage, they are more prone to experience depression due to worsening and life-threatening health conditions that interfere with daily activities and cause them to depend on other people so that they often require special treatment in the hospital which causes them to lose social contacts. In addition, patients also often feel that their life is short so that whatever is done will be in vain. This will have an impact on their quality of life [8]. According to Lubis (2016), there is a significant correlation between depression and the quality of life of people with HIVIAIDS in Medan, Indonesia. It indicates that a higher depression level causing low quality of life [9]. Therefore, the authors are interested in examining the correlation between the Beck Depression Inventory (BDI) and the World Health Organization Quality Of Life (WHOQOL-BREF) Scores in Stage III HIVIAIDS Patients at Pusyansus RSUP Haji Adam Malik Medan.

\section{Methods}

This study is a correlative analytic study with a cross-sectional approach, which describes and analyzes a situation at a certain time, which assesses the correlation between the BDI II score and the WHOQOL-BREF score in HIVIAIDS stage III patients at the central public hospital, namely Pusyansus RSUP Haji Adam Malik Medan, Indonesia. This study was conducted from May 2019 to November 2019.

The objects of this study were including patients with HIVIAIDS Stage III at RSUP Haji Adam Malik who has been visited the hospital during the period of time from May 2019 to November 2019. Furthermore, the patients will be selected based on the inclusion criteria. Inclusion criteria for selecting research samples were men and women with Stage III HIVIAIDS aged range of 18 years old $\leq$ research subjects $\leq 60$ years old, able to read and write, never been diagnosed with a depressive disorder, willing to participate in the study (signed the informed consent). The exclusion criteria were suffering from severe physical impairment (paralyzed) and 
suffering from psychiatric and other disorders. Selected patients who have met the inclusion criteria and signed the informed consent were asked to fill BDI II and WHOQOL-BREF questionnaires. The sample in this study was determined using a non-probability sampling type of consecutive sampling where all subjects who came sequentially and met the selection criteria were included in the study until the required number of subjects was met.

The BDI II and WHOQOL-BREF Scores variables were analyzed to determine its correlation. The normality of data distribution was first tested using the Kolmogorov-Smirnov test because the number of samples is more than 50 . If the two variables are normally distributed or at least one of the variables is normally distributed and the linearity is met, the correlation between two scores was analyzed based on Pearson correlation test.

\section{Results}

The demographic characteristics of selected patients for this study can be seen in Table 1. It can be seen clearly that most patients were male $(66.20 \%)$ and the work status was dominated by unemployment $(66.20 \%)$. The selected patients were majorly unmarried (58.50\%). The highest level of education was junior high school and senior high school (41.50\% of each). Their ages were in the range of $31-40$ years old $(44.60 \%)$.

Table 1: Sample distribution based on demographic characteristics

\begin{tabular}{|c|c|}
\hline & $\mathrm{n}(\%)$ \\
\hline \multicolumn{2}{|l|}{ Gender } \\
\hline Men & $43(66.20)$ \\
\hline Women & $22(33.80)$ \\
\hline \multicolumn{2}{|l|}{ Age } \\
\hline $18-30$ years old & $19(29.2)$ \\
\hline $31-40$ years old & $29(44.6)$ \\
\hline $41-60$ years old & $17(26.2)$ \\
\hline \multicolumn{2}{|l|}{ Occupation status } \\
\hline Employee & $22(33.80)$ \\
\hline Unemployment & $43(66.20)$ \\
\hline \multicolumn{2}{|l|}{ Marital status } \\
\hline Married & $27(41.50)$ \\
\hline Unmarried & $38(58.50)$ \\
\hline \multicolumn{2}{|l|}{ Educational level } \\
\hline Elementary school & $3(4.60)$ \\
\hline Junior high school & $27(41.50)$ \\
\hline Senior high school & $27(41.50)$ \\
\hline University & $8(12.30)$ \\
\hline \multicolumn{2}{|l|}{ HIVIAIDS duration of illness } \\
\hline $1-5$ years & $43(66.2)$ \\
\hline$>5-10$ years & $18(27.7)$ \\
\hline$\geq 10$ years & $4(6.2)$ \\
\hline \multicolumn{2}{|l|}{ BDI II Score } \\
\hline Mean \pm S.D. & $34.67 \pm 1.41$ \\
\hline \multicolumn{2}{|l|}{ WHOQOLBREFdomain 1 score } \\
\hline Median (minmax) & \\
\hline \multicolumn{2}{|l|}{ WHOQOLBREFdomain 2 score } \\
\hline Median (minmax) & $44(38-69)$ \\
\hline \multicolumn{2}{|l|}{ WHOQOLBREFdomain 3 score } \\
\hline Median (minmax) & $44(19-81)$ \\
\hline \multicolumn{2}{|l|}{ WHOQOLBREFdomain 4 score } \\
\hline Median (minmax) & $44(6-100)$ \\
\hline
\end{tabular}

The most duration of illness was found to be $1-4$ years $(66.20 \%)$.

The demographic characteristics of selected patients for this study can be seen in Table 1 . It can be seen clearly that most patients were male $(66.20 \%)$ and the work status was dominated by unemployment $(66.20 \%)$. The selected patients were majorly unmarried (58.50\%). The highest level of education was junior high school and senior high school (41.50\% of each). Their ages were in the range of $31-40$ years old $(44.60 \%)$. The most duration of illness was found to be $1-4$ years $(66.20 \%)$.

Based on the Pearson correlation test (Table 2), it was found that $p<0.001$ (very significant) and a correlation value of $r=-0.43$ (negatively correlated with moderate correlation strength) with a total of 65 subjects.

Table 2: Correlation between BDI II and WHOQOLBREF domain 1 scores

\begin{tabular}{|c|c|c|c|c|c|}
\hline & Mean \pm SD & & $P$ & $R$ & $\mathrm{~N}$ \\
\hline BDI II Score & $34.67 \pm 1.41$ & $44(38-63)$ & $<0.001$ & -0.43 & 65 \\
\hline
\end{tabular}

Table 3 shows the correlation between the BDI score and the WHOQOL-BREF Domain 2 score. From the results of the Pearson correlation test, it was found that $p<0.001$ (very significant) and a correlation value of $r=-0.45$ (negatively correlated with moderate correlation strength) with a total of 65 subjects.

Table 3: Correlation between BDI II and WHOQOLBREF domain 2 scores

\begin{tabular}{|c|c|c|c|c|c|}
\hline & Mean \pm SD & & $P$ & $R$ & $\mathrm{~N}$ \\
\hline BDI II Score & $34.67 \pm 1.41$ & & & & \\
\hline $\begin{array}{l}\text { WHOQOLBREF domain } 2 \\
\text { Score Median (minmax) }\end{array}$ & & $44(38-69)$ & $<0.001$ & -0.45 & 65 \\
\hline
\end{tabular}

Table 4 shows the correlation between the BDI score and WHOQOL-BREF Domain 3 score. Based on the Pearson correlation test, it was found that $p<0.001$ (very significant) and a correlation value of $r=-0.47$ (negatively correlated with moderate correlation strength) with a total of 65 subjects.

Table 4: Correlation between BDI II and WHOQOLBREF domain 3 scores

\begin{tabular}{|c|c|c|c|c|c|}
\hline & Mean \pm SD & & $\mathrm{P}$ & $\mathrm{R}$ & $\mathrm{N}$ \\
\hline BDI II Score & $34.67 \pm 1.41$ & & & & \\
\hline $\begin{array}{l}\text { WHOQOLBREF domain } \\
3 \text { Score Median (minmax) }\end{array}$ & & $44(19-81)$ & $<0.001$ & -0.47 & 65 \\
\hline
\end{tabular}

Table 5 shows the correlation between BDI and WHOQOL-BREF Domain 4 scores. Based on the Pearson correlation test, it was found that $p<0.001$ (very significant) and the correlation value $r=-0.615$ (negatively correlated with strong correlation strength) with a total of 65 subjects.

Table 5: Correlation between BDI II and WHOQOLBREF domain 4 scores

\begin{tabular}{|c|c|c|c|c|c|}
\hline & Rerata \pm SB & & $P$ & $R$ & $\mathrm{~N}$ \\
\hline BDI II Score & $34.67 \pm 1.41$ & & & & \\
\hline $\begin{array}{l}\text { WHOQOLBREF domain } \\
3 \text { Score Median (minmax) }\end{array}$ & & $44(6-100)$ & $<0.001$ & -0.615 & 65 \\
\hline
\end{tabular}




\section{Discussion}

This study was conducted to assess the correlation between BDI II and the WHOQOL-BREF scores in stage III HIVIAIDS patients at Pusyansus RSUP Haji Adam Malik Medan.

The gender distribution of most subjects was men $(66.2 \%)$. This result is in accordance with the data recorded by the Ministry of Health of Indonesia; $74.8 \%$ of the total number of HIV patients in Indonesia was dominated by men. Imazu et al. (2017) was found that the majority of HIVIAIDS patients were men $(96.8 \%)^{10}$ and in addition, Sun et al. (2014) also found in their research study that the HIVIAIDS patients were also dominated by men (89.50\%) [11].

Based on the age parameter, the most age obtained was in the range of 31-40 years old. According to the data from the Directorate General of P2P of the Indonesian Ministry of Health and the Directorate General of PP\&PL of the Indonesian Ministry of Health, it was found that the highest prevalence for people with HIVIAIDS and people who are at risk of acquiring HIV infection is at the productive age, namely $25-49$ years old [12].

In this study, it was obtained that HIVIAIDS patients as research subjects were majorly unemployed. According to Chkhartishvili et al. (2011), out of 218 research subjects, $163(74.77 \%)$ were unemployed while the rest were employed [13]. According to Nojomi et al., the occupation of people has a significant effect on the quality of life [14].

In this study, more subjects were unmarried [11]. According to Greef et al. (2015), marital status is one of the factors that affect the quality of life of HIV patients/ AIDS [15]. Individuals who are unmarried and divorced have a worse quality of life than individuals who are married.

In this study, the highest levels of education were junior high school and senior high school. The results of this study are not in accordance with Sun et al. in 2014 , who got $43.3 \%$ of research subjects were elementary school, it has been explained in their research that low education level leads to low quality of life compared to highly educated individuals [11].

Based on the results of this study, the BDI II score indicates moderate depression. This is in line with research conducted by Bathia, which reports that depression will increase in number due to the severity of HIVIAIDS [6].

There is a significant correlation between BDI scores and WHO-QOL domain 1 scores in this present study, namely physical health in patients with stage III HIVIAIDS. In addition, the negative correlation with moderate correlation strength indicates that the higher the BDI score, the lower the WHOQOL-BREF score will be generated. In the physical domain, PLWHA are basically able to carry out activities related to physical treatment and medication, such as exercise, adequate sleep, and regular use of drugs. This is evidenced by the number of PLWHA who answered in the category very often, satisfying, and mediocre for all questions about physical. Respondents responded that the physical pain caused by HIVIAIDS disrupted their physical activity and caused discomfort while sleeping. With physical exhaustion, muscles will hardly work. With mental exhaustion, the ability to concentrate will be decreased. A study by Basavaraj et al. 2010 stated that fatigue or low energy has been associated with both physical and psychological morbidity and poor quality of life in patients with HIVIAIDS [16]

There is a significant correlation between the BDI II and the WHO-QOL domain 2 scores, which is psychological in patients with stage III HIVIAIDS. In addition, a negative correlation with moderate correlation strength indicates that the higher the BDI score, the lower the WHOQOL-BREF score. In the psychological domain question, how often to enjoy life and how often to be able to concentrate, there was only one respondent $(4.8 \%)$ who answered the category very often. The reason is that respondents often feel feeling blue (loneliness, hopelessness, anxiety, and depression), so it can be said that the quality of life of PLWHA from a psychological perspective is not good. According to Cella (2016), a state of depression can make patients pessimistic about the future, seeing themselves as worthless, tend to shut themselves up and not hang out with other people and think of themselves as people who are cursed by God, so that this will affect the overall aspects of the patient's quality of life. About $72.65 \%$ of PLWHA said that their life was not as good as other people's lives; besides that, PLWHA also experienced physical problems where $42.3 \%$ of PLWHA felt weak and $41.88 \%$ of PLWHA experienced sleep disorders [17].

There is a very significant correlation between BDI II and WHO-QOL domain 3 scores, namely social in patients with stage III HIVIAIDS. In addition, a negative correlation with moderate correlation strength indicates that the higher the BDI score, the lower the WHOQOL-BREF score. As a result of questions related to the social domain, how the patients feel accepted in the society, there was $38.1 \%$ of patients answered moderate. They feel that they are in the category of being accepted because there are still people who want to mingle with respondents even though they already know their HIV status, there are still those who care, even there are people who provide support for them. No respondent $(0 \%)$ answered that the sexual relationship and friend's support were very satisfying. This happens because they feel excluded from friends and even from their own families who know that they have been diagnosed with HIVIAIDS. The main reason PLWHA feels this way is because, for PLWHA, one of 
the biggest social problems they experience is social isolation from family and society. Stigma has a very serious impact on HIV-positive people and on HIV control efforts as a whole. PLWHA are reluctant to seek the health services and social support they should be able to get. Many PLWHVA have to lose their jobs or lose the opportunity to get a job, insurance, other public services, even a child can be refused education at school [18]. The incidence of depression was more common in HIV patients with poor social support [6]. According to Amiya et al. (2014), family support in the incidence of depression and suicide among PLWHA has the most important role [19].

There is a significant correlation between the BDI and the WHO-QOL domain 4 scores, which is psychological in patients with stage III HIVIAIDS. In addition, a negative correlation with strong correlation strength indicates that the higher the BDI score, the lower the WHOQOL-BREF score. In the environmental domain, the frequency of feeling safe, how healthy the living environment is the need for money, and recreational opportunities, there were no respondents $(0 \%)$ who answered none at all. This happens because a lack of understanding about HIV and AIDS results in people who suffer from this disease often isolated from their environment so that patients tend to close themselves. Environment, namely satisfaction with physical security, home environment, financial resources, health services, access to information, opportunities to participate in recreational activities, physical environment (pollution, noise, weather, etc.), and transportation services [20].

This study is in accordance with the results of research by Lubis (2016) in Medan which shows a significant correlation between depression and the quality of life of people with HIVIAIDS ( $r=-0.59, p=0.001)$, where the higher the depression, the lower the quality of life will be generated. Similar research was also conducted by Fatigerun which resulted in the lowest quality of life in the domain of environment and social relations so that living conditions decreased and resulted in decreased quality of life [9].

\section{Conclusions}

1. The most demographic characteristics of HIV/ AIDS sufferers in RSUP Haji Adam Malik were men $(66.20 \%)$. Most of the work status was unemployed $(66.20 \%)$. Most of the marital status was unmarried $(58.50 \%)$. The highest levels of education were junior and senior high schools (41.50\%).

2. There is a BDI II score with a mean \pm SD 34.67 \pm 1.41 indicating moderate depression.

3. There was a significant correlation between
BDI II and WHO-QOL Domain 1 score in patients with HIVIAIDS Stage III with a $\mathrm{p}<$ 0.001 . Pearson correlation value of -0.431 indicates a negative correlation with moderate correlation strength.

4. There was a significant correlation between BDI II and WHO-QOL Domain 2 score in patients with HIVIAIDS Stage III with a $\mathrm{p}<$ 0.001 . Pearson correlation value of -0.450 indicates a negative correlation with moderate correlation strength.

5. There was a significant correlation between BDI II and WHO-QOL Domain 3 score in patients with HIVIAIDS Stage III with a $\mathrm{p}<$ 0.001 . Pearson correlation value of -0.473 indicates a negative correlation with moderate correlation strength.

6. There was a significant correlation between BDI II and WHO-QOL Domain 4 score in patients with HIVIAIDS Stage III with a $\mathrm{p}<$ 0.001 . Pearson correlation value of 0.615 indicates a negative correlation with strong correlation strength.

\section{Recommendations}

1. This study suggests a correlation between BDI scores and WHOQOL-BREF scores in patients with Stage III HIVIAIDS that can provide a scientific contribution that shows that the higher the BDI score, the lower the WHOQOLBREF score.

2. For future study, it is hoped that this study can become a reference material for assessing the correlation between BDI scores and WHOQOL-BREF scores in patients with Stage III HIVIAIDS.

\section{References}

1. Williams BG, Dye C. Antiretroviral drugs for tuberculosis contro in the era of HIV/AIDS. Science. 2003;301(5639):1535-7. https://doi.org/10.1126/science.1086845 PMid:12920302

2. Helti MR, Asfriyati, Abdul Jalil A. Perilaku transgender (Waria) dalam upaya pencegahan Hiv/Aids Di puskesmas teladan kota medan tahun 2016. J STIKNA. 2017;1(2):158-64.

3. Terloyeva D, Nugmanova Z, Akhmetova G, Akanov A, Patel N, Lazariu $\mathrm{V}$, et al. Untreated depression among persons living with human immunodeficiency virus in Kazakhstan: A crosssectional study. PLoS One. 2018;13(3):e0193976. https://doi. org/10.1371/journal.pone.0193976

4. Dinas Kesehatan Provinsi Sumatera Utara. Laporan Program HIVIAIDS dan IMS Provinsi Sumatera Utara Tahun 2015, Medan; 2016. https://doi.org/10.32315/ti.8.e025

5. Hemert D, Vijver F. The beck depression inventory as a measure of subjective well-being: A cross-national study. J Happiness 
Stud. 2002;3:257-86.

6. Bhatia MS, Munjal S. Prevalence of depression in people living with HIVIAIDS undergoing ART and factors associated with it. J Clin Diagn Res. 2014;8(10):WC01-4. https://doi.org/10.7860/ jcdr/2014/7725.4927

\section{PMid:25478433}

7. Cooper V, Clatworthy J, Harding R, Whetham J, Consortium E. Measuring quality of life among people living with HIV: A systematic review of reviews. Health Qual Life Outcomes. 2017;15:220. https://doi.org/10.1186/s12955-017-0778-6 PMid:29141645

8. Elbadawi A, Mirghani H. Depression among HIV/AIDS Sudanese patients: A cross-sectional analytic study. Pan Afr Med J. 2017;26:43. https://doi.org/10.11604/pamj.2017.26.43.10919 PMid:28451021

9. Lubis M, Sarumpaet SM. Correlation of stigma, depression, and fatigue with quality of life among HIVIAIDS patients in Klinik Veteran Medan. Idea Nurs J 2016;7(1):1-12.

10. Imazu R, Matsuyama N, Takebayashi S, Mori M, Watabe S. Experiences of patients with HIVIAIDS receiving mid- and long-term care in Japan: A qualitative study. Int J Nurs Sci. 2017;4(2):99-104. https://doi.org/10.1016/j.ijnss.2017.02.004 PMid:31406727

11. Sun W, Wu M, Qu P, Lu C, Wang L. Psychological wellbeing of people living with HIVIAIDS under the new epidemic characteristics in China and the risk factors: A population-based study. Int J Infect Dis. 2014;28:147-52. https://doi.org/10.1016/j. ijid.2014.07.010

12. Ditjen PP, PL Kemenkes RI. Statistik Kasus HIVIAIDS di Indonesia Dilapor s/d Juni; 2013. Avaible from: http://www. spiritia.or.id/stats/statcurr.pdf. [Last accessed on 2019 Nov 03].

13. Chkhartishvili N, McNutt LA, Smith PF, Tsertsvadze T.
Characteristics of HIV-infected women and factors associated with HCV seropositivity in the republic of Georgia. AIDS Res Ther. 2011;8(1):25. https://doi.org/10.1186/1742-6405-8-25 PMid:21787384

14. Nojomi M, Anbary K, Ranjbar M. Health-related quality of life in patients with HIVIAIDS. Arch Iran Med. 2016;11(6):608-12. PMid:18976030

15. Greef M, Uys LR, Wantland D, Makoae L, Chirwa M, Dlamini P, et al. Perceived HIV stigma and life satisfaction among persons living with HIV infection in five African countries: A longitudinal study. Int J Nurs Stud 2010;47(4):475-86. https:// doi.org/10.1016/j.jnurstu.2009.09.008

16. Basavaraj K, Navya M, Rashmi R. Quality of life in HIVIAIDS. Indian J Sex Transm Dis AIDS. 2010;31(2):75-80. https://doi. org/10.4103/0253-7184.74971 PMid:21716787

17. Cella D. Quality of life. In: Psychooncology. New York: Oxford Univercity; 2016.

18. Kemenkes RI. Data dan Informasi Profil Kesehatan Indonesia; 2017.

19. Amiya RM, Poudel KC, Poudel-Tandukar K, Pandey BD, Jimba M Perceived family support, depression, and suicidal ideation among people living with HIVIAIDS: A cross-sectional study in the Kathmandu Valley, Nepal. PLoS One J. 2014;9(3):e90959. https://doi.org/10.1371/journal.pone.0090959

PMid:24603886

20. Sayles JN, Ryan GW, Silver JS, Sarkisian CA, Cunningham WE. Experiences of social stigma and implications for healthcare among a diverse population of HIV positive adults. J Urban Health. 2007;84(6):814-28. https://doi.org/10.1007/ s11524-007-9220-4

PMid:17786561 